$1-1-1925$

\title{
Varietal Experiments with Soybeans
}

Ralph John Garber

T. E. Odland

T. E. Mcllvaine

K.S. Quisenberry

Follow this and additional works at: https://researchrepository.wvu.edu/ wv_agricultural_and_forestry_experiment_station_bulletins

\section{Digital Commons Citation}

Garber, Ralph John; Odland, T. E.; McIlvaine, T. E.; and Quisenberry, K. S., "Varietal Experiments with Soybeans" (1925). West Virginia Agricultural and Forestry Experiment Station Bulletins. 196.

https://researchrepository.wvu.edu/wv_agricultural_and_forestry_experiment_station_bulletins/196 @ WVU. It has been accepted for inclusion in West Virginia Agricultural and Forestry Experiment Station Bulletins by an authorized administrator of The Research Repository @WVU. For more information, please contact ian.harmon@mail.wvu.edu. 


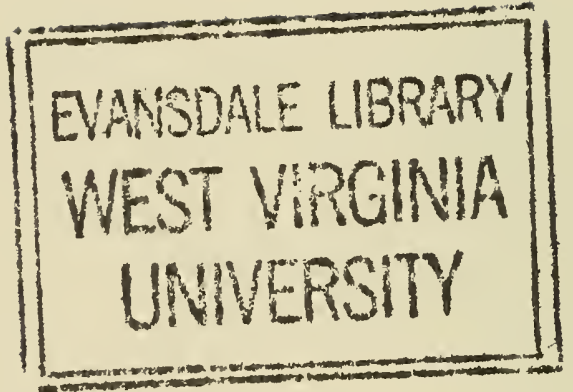


Restricted

\section{Circulation Only}

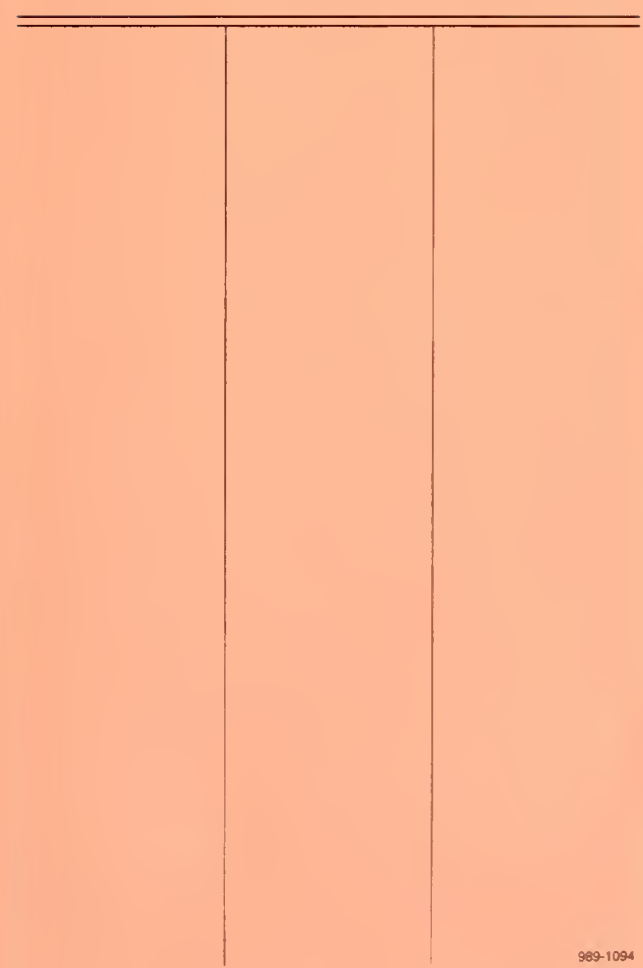





\title{
Aqricultural Experiment Station
}

College of Agriculture, raest Virginia annibersity

\author{
HENRY G. KNIGHT, Director \\ Morgantown
}

\section{Varietal Experiments With}

\section{Soybeans}

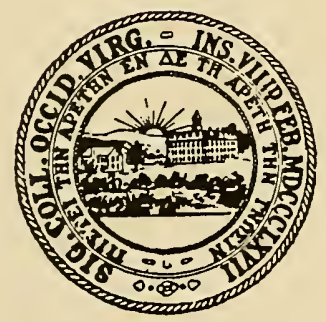

BY

R. J. GARBER, T. E. ODLAND,

T. C. MCILVAINE, K. S. QUISENBERRY 


\section{AGRICULTURAL EXPERIMENT STATION STAFF}

FRANK B. TROTTER, A. M., LL. D. .........- President of the University GEORGE R. LYMAN, Ph. D. -.......- Dean of the College of Agriculture HENRY G. KNIGHT, Ph. D. -...-_-- Director of the Experiment Station WALTER C. SCHNOPP, B. S. Agr. Agricultural Editor JOHN C. JOHNSTON Chief Clerk

\section{AGRONOMY}

R. J. Garber, Ph. D.

T. E. Odland, M. S. Associate Agronomist T. C. McIlvaine, $\mathrm{Ph} . \mathrm{D} . \dagger$

Assistant Agronomist

M. M. Hoover, M. S.

Junior Agronomist

H. K. Rowley, B. S. Agr.** Seed Analyst

\section{ANIMAL HUSBANDRY}

E. A. Livesay, M. S.

Animal Husbandman

Chas. V. Wilson, M. S.

Assistant Animal Husbandman

E. C. Stillwell, M. S.

Assistant Animal Husbandman

R. H. Tuckwiller, B. S. Agr.*

Assistant Animal Husbandman

\section{CHEMISTRY}

Henry G. Knight, Ph. D.

Chemist

R. B. Dustman, Ph. D.

Assistant Chemist

Chas. E. Weakley, Jr., B. A.

T. B. Leith, B. A.**

Assistant Chemist

T. J. Cochran, B. S.

Assistant Chemist

Junior Chemist

\section{DAIRY HUSBANDRY}

Ernest L. Anthony, M. S. Agr.

Dairy Husbandman

H. O. Henderson, M. S. Agr.

Associate Dairy Husbandman

Warren Gifford, B. S. Agr. $\dagger_{\dagger}$

Junior Dairy Husbandman

G. M. Trout, M. S.

Assistant in Dairy Husbandry

\section{ENTOMOLOGY}

L. M. Peairs, Ph. D.

W. E. Rumsey, B. S. **

Entomologist

State Entomologist
FARM ECONOMICS

A. J. Dadisman, Ph. D.

Paul A. Eke, Ph. D.

Junior Farm Economist

F. D. Cornell, M. S.

Junior Farm Mechanician

W. W. Armentrout, M. S.

Junior Farm Economist

\section{HORTICULTURE}

M. J. Dorsey, Ph. D. ***

H. L. Crane, M. S. Agr.

Horticulturist

Associate Horticulturist

H. E. Knowlton, Ph. D.

Associate Horticulturist

K. C. Westover, M. S. Agr.

Assistant Horticulturist Ernest Angelo, B. S. Agr.

Junior Horticulturist

L. F. Sutton, B. S. Agr. $\dagger$

Assistant Horticulturist

Troy M. Currence, B. S. Agr.

Assistant in Horticulture

\section{PLANT PATHOLOGY}

N. J. Giddings, $\mathrm{Ph}$. D

Anthony Berg, B. S.

Plant Pathologist

Assistant Plant Pathologist

L. H. Leonian, Ph. D.

Assistant Plant Pathologist

E. C. Sherwood, M. S.

Assistant Plant Pathologist

POULTRY HUSBANDRY

Horace Atwood, M. S. Agr.

Poultry Husbandman

SOILS

E. P. Deatrick, Ph. D.

Associate Soil Technologist

*In co-operation with the U. S. Department of Agriculture, Washington, D. C.

**In co-operation with the State Department of Agriculture, Charleston, W. Va.

*** Resigned September 1, 1925.

†In charge of the Reymann Memorial Farms, Wardensville, W. Va.

IIn charge of the Magzie Sub-Station, Maggie, W. Va.

t†On leave of absence. 


\section{Varietal Experiments With Soybeans}

Soybeans are rapidly becoming one of the most important leguminous crops grown in West Virginia. Their increasing popularity is well deserved as they possess characteristics which peculiarly fit them to occupy a prominent position in the future development of agriculture in this state.

Soybeans are adapted to a wide range of both soil and climate. They will thrive on almost any soil but seem to give best results on good corn land. They are less sensitive to acid than such legumes as alfalfa, sweet clover, and red clover. This characteristic makes them especially well suited for West Virginia conditions. Soybeans are grown successfully all the way from Canada to the Gulf States and therefore it is not surprising to find that they grow well at both the higher and the lower altitudes in West Virginia.

Stock farmers are well aware of the importance of leguminous roughage in raising livestock, but under certain conditions it has not always been feasible to produce the desired amount. The soybean often affords an easy way out of this difficulty. The crop is easily grown and it possesses a high feeding value.

One problem that usually confronts the farmer who is growing soybeans for the first time is the choice of a variety. The object of this bulletin is to present the results of certain varietal experiments that have been carried on at the Agronomy Farm near Morgantown and at the Maggie Substation located in Mason County. Before discussing the results of the varietal experiments it may be well to present very briefly certain cultural practices that should be observed in growing soybeans.

\section{CULTURAL PRACTICES}

Soybeans are usually planted just after corn planting time. There is nothing gained by planting this crop before the ground has thouroughly warmed. The seeds should not be planted more than one to two inches deep except on light sandy soil where it may be necessary to plant somewhat deeper to obtain sufficient moisture for germination.

If the soybeans are to be grown for hay, solid drilling usually gives best results. If the land is extremely weedy it may be advisable to grow the soybeans in cultivated rows although the hay produced under this condition is coarser that when they are grown in 
solid drill rows or broadcast. When grown in solid drill rows anywhere from four to eight pecks of seed per acre are sown depending somewhat on the individual size and the cost of the seed. At present the Agronomy Department has under way an experiment to determine the rate of seeding of Wilson soybeans that gives the highest yield and the best quality of hay. The details of this experiment will be published later. It suffices here to state that the results thus far indicate that the heavier rates of seeding produce hay of finer quality and freer from weeds than the lighter rates.

If the soybeans are to be grown for seed it is best to grow them in rows that may be cultivated. The rows are usually from twentyfour to thirty-six inches apart. The soybeans may be planted with a corn planter or with a grain drill having some of the holes plugged. When seeded in cultivated rows about thirty pounds of seed per acre are required.

When harvested for hay soybeans should be cut when the pods are well filled but before the leaves turn yellow. The plants become woody if allowed to stand too long. When harvested for seed the crop is left standing until the pods are ripe but cut before the seeds begin to shatter out. Some varieties such as Medium Green shatter rather easily.

Soybeans cut for hay should be allowed to wilt thoroughly, and then be placed in small cocks. Under favorable conditions it takes four or five days to complete the curing after the hay has been cocked. During wet weather it is well to place the hay on pyramid-like racks which may be made by fastening together at one end three or four uprights each about four feet long. A rack or shock support such as this provides an air space within the cock and facilitates curing. Under some conditions canvass cock covers may prove a paying investment.

When soybeans are cut for seed they may be harvested with a twine binder and the bundles set up in medium sized shocks until threshed. If a binder is not available the soybeans may be cut with an ordinary mowing machine but provision should be made to prevent the horses from tramping the cut swath. This is sometimes done by fastening a buncher attachment to the cutter bar or by having a man follow the machine and push the cut swath to one side.

Soybeans may be threshed with a bean huller or with an ordinary grain thresher. If the latter is used the speed of the cylinder should be reduced about one-half or to about 500 reovlutions per minute and 
the remainder of the machine maintained at the ordinary rate of speed. This may be done by increasing the size of the pulleys on the cylinder shaft. Sometimes it is necessary to remove some of the concaves to prevent splitting the seeds. If only a small acreage is grown it is entirely practical to flail out the seed by hand.

After the soybeans are threshed the seed should be spread out in a thin layer on the floor of a well ventilated storage room until thoroughly dry. If the seed is allowed to heat it soon loses its ability to germinate. After the seed is dry it may be placed in burlap sacks and stored in a dry, well ventilated room. Even here it is desirable to provide for a limited amount of air circulation between the bags containing the seed. After soybean seed is one year old it ordinarily loses its germinating ability very rapidly.

Perhaps one of the most frequent causes of failure in first attempts to grow soybeans may be attributed to the lack of proper inoculation. Soybeans will grow without inoculation on a very productive soil but under such circumstances they behave like any non-leguminous plant and draw practically their entire supply of nitrogen from the soil. On unproductive soil inoculation is essential to grow soybeans successfully. Once a field has been inoculated there is evidence which indicates that the bacteria may live in the soil for several years even though soybeans are not grown during that time. Soybeans apparently are not cross inoculated with other legumes commonly cultivated, that is, the bacteria which live in the nodules of soybeans will not inoculate the other legumes and the bacteria found in the nodules of the latter will not inoculate soybeans.

There are two general ways of inoculating soybeans which may be classified as the pure culture method and the soil method. If the former is used a pure culture containing the soybean bacteria may be purchased from almost any of the commercial seed houes or a limited supply of the inoculum may be obtained without cost from the United States Department of Agriculture, Bureau of Plant Industry, Soil Bacteriology Investigations, Washington, D. C. Complete diiections for inoculating are sent with all pure cultures.

The soil method of inoculating is entirely effective and is easily done. The manner of proceeding is commonly as follows: Obtain soil (about one quart of soil to each bushel of soybeans to be inoculated) at a depth of from one to three inches below the surface in a 
field that has recently grown soybeans and which was known to have been inoculated, or better, obtain the soil from around the inoculated roots of soybean stubble and allow the soil thus obtained to dry in the shade. After the soil is dried it should be finely pulverized and sifted if necessary to remove the coarse particles. The soil is now ready to be applied to the soybeans. This is done by first slightly moistening (not wet) the seed with a fine spray of water and then dusting the soil over the moistened seed. During the process the seed should be thoroughly stirred and mixed in order to make certain that each seed receives first a film of moisture and then a coating of dust. Sometimes a little glue or sugar is added to the water in order that the solution may hold the soil dust more effectively. This precaution does not seem to be necessary for successful inoculation. The seed may be planted while it is still moist or after it has been allowed to dry.

Another method of inoculation is to obtain the soil and treat it as described above but to obtain it in somewhat larger quantities (about one peck of soil to each bushel of soybeans). In this method, the soil after it is dried, pulverized, and sifted is simply placed on top of the soybeans in the planter box or drill box and planted with the seed. Somewhat more soil is required with this method than with the other soil method. In view of the fact that the inoculation of soybeans is so easily accomplished and the further fact that inoculation is so essential to successful soybean production, no grower can afford to disregard it.

\section{METHODS USED IN EXPERIMENTS}

The varietal experiments at the Agronomy Farm were carried on in plots consisting of four rows eighteen feet long and thirty inches apart. Each variety was grown in four such plots systematically distributed over the experimental area. In 1921 every fourth plot, and in 1922,1923 , and 1924 every sixth plot, was planted with the variety "Wilson 89" as a check. Inoculated seed was planted by hand and single seeds spaced approximately one inch apart in the rows.

Sixteen feet of one of the inner rows of each plot was harvested for yield of hay and sixteen feet of the other inner rows for yield of seed. Approximately one foot of the end of each inner row was discarded to eliminate border influence. The yield of a variety each year was based on the average yield of four such inner rows taken from as many plots.

The yields of hay per acre are expressed in tons of air dry material. At the time a variety was cut for hay a weighed sample of the green material was taken from each row harvested and dried to deter- 


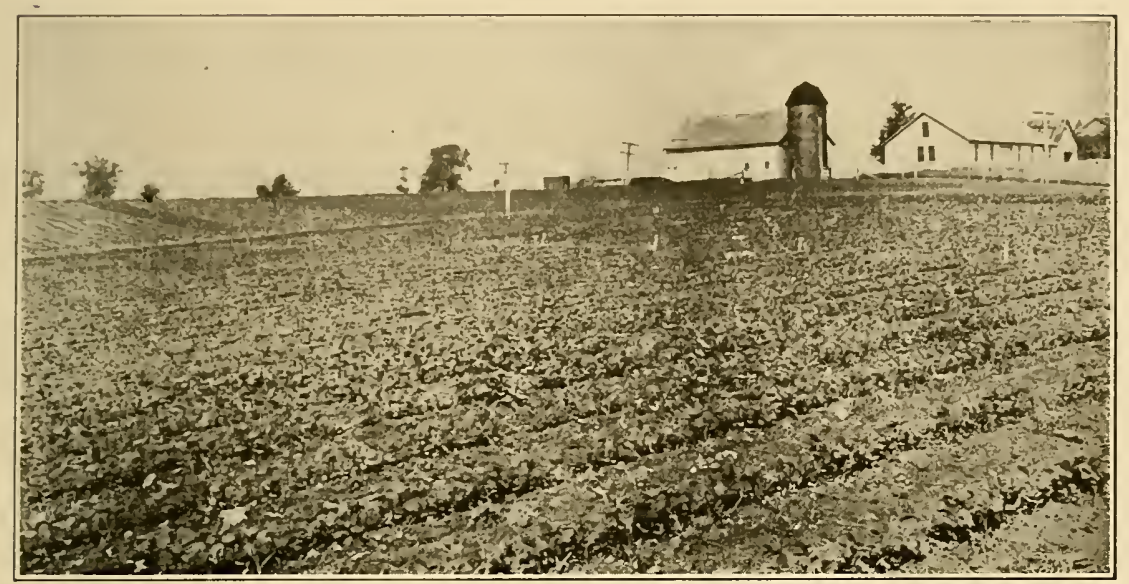

Soybean Variety Plots on the Agronomy Farm at an Early Stage of Growth

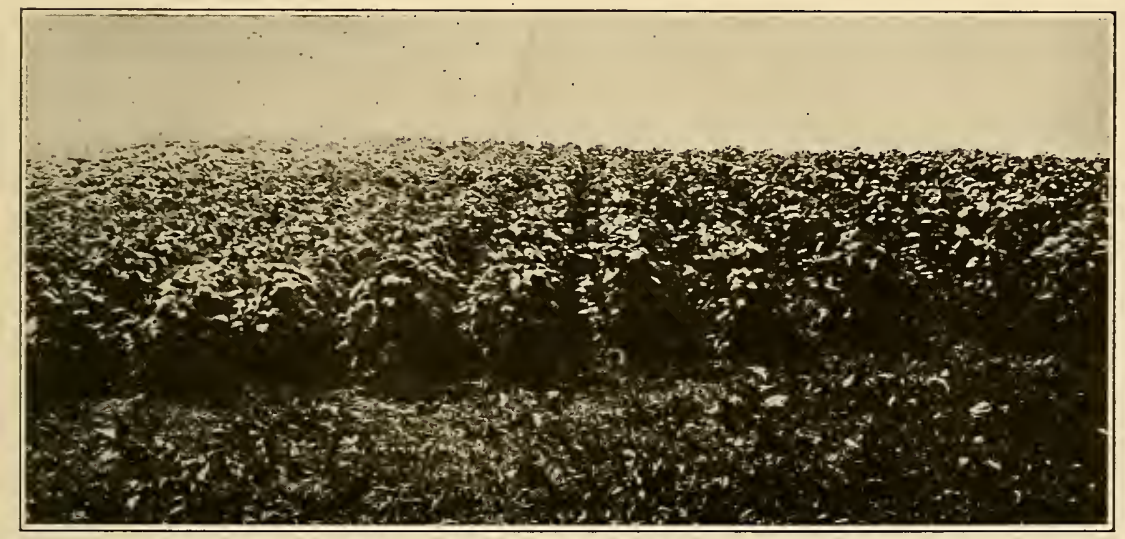

Variety Plots of Soybeans Growing on the Agronomy Farm Near Maturity 
mine the air dry weight. Each variety was cut for hay when the pods were well filled.

When a variety was sufficiently matured for seed the remaining inner rows were cut and placed separately in loosely woven gunny bags. The bags were then hung in a well ventilated shed until the soybeans were dry after which they were threshed with a small thresher. Immediately after threshing the seed was weighed and later the yield in bushels per acre computed.

In addition to the yield data notes were taken on general habits of growth, such as height of plant, character of growth (viny, erect, or bushy), retention of leaves, quality of stem (coarse, medium, or fine), and number of days to mature. The color of the seed was also recorded.

The varietal experiments at Maggie were carried on in a manner similar to those on the Agronomy Farm. In 1922 there were no border rows used in the test at Maggie and the rows were approximately forty feet long instead of eighteen feet as in the other tests. In addition to the yield data the only note taken was the number of days from planting to maturity for hay in 1923 and 1924 . The experiments at Maggie have been carried on for three years and those on the Agronomy Farm for four years.

In interpreting the significance of the difference in yield between certain varieties the method suggested by Student* has been used.

\section{EXPERIMEN'TS ON THE AGRONOMY FARM}

There were 26 varieties and pure line selections of soybeans included in the varietal experiments on the Agronomy Farm. All of them were grown for a period of four years and tested from the standpoint of both seed and forage yields. The varieties grown, the average number of days required to mature seed and the yield of seed in bushels per acre are listed in Table $I$.

An examination of column 2 shows that Ito San, Ohio 9100, which is a selection from Ito San, and S. P. I. 36916 were the three earliest maturing varieties and Haberlandt, Virginia, Mikado and Peking were the four latest maturing varieties in the test. With the exception of Haberlandt the varieties which gave the highest average yields of seed were intermediate betwen the late and early varieties in maturity. 


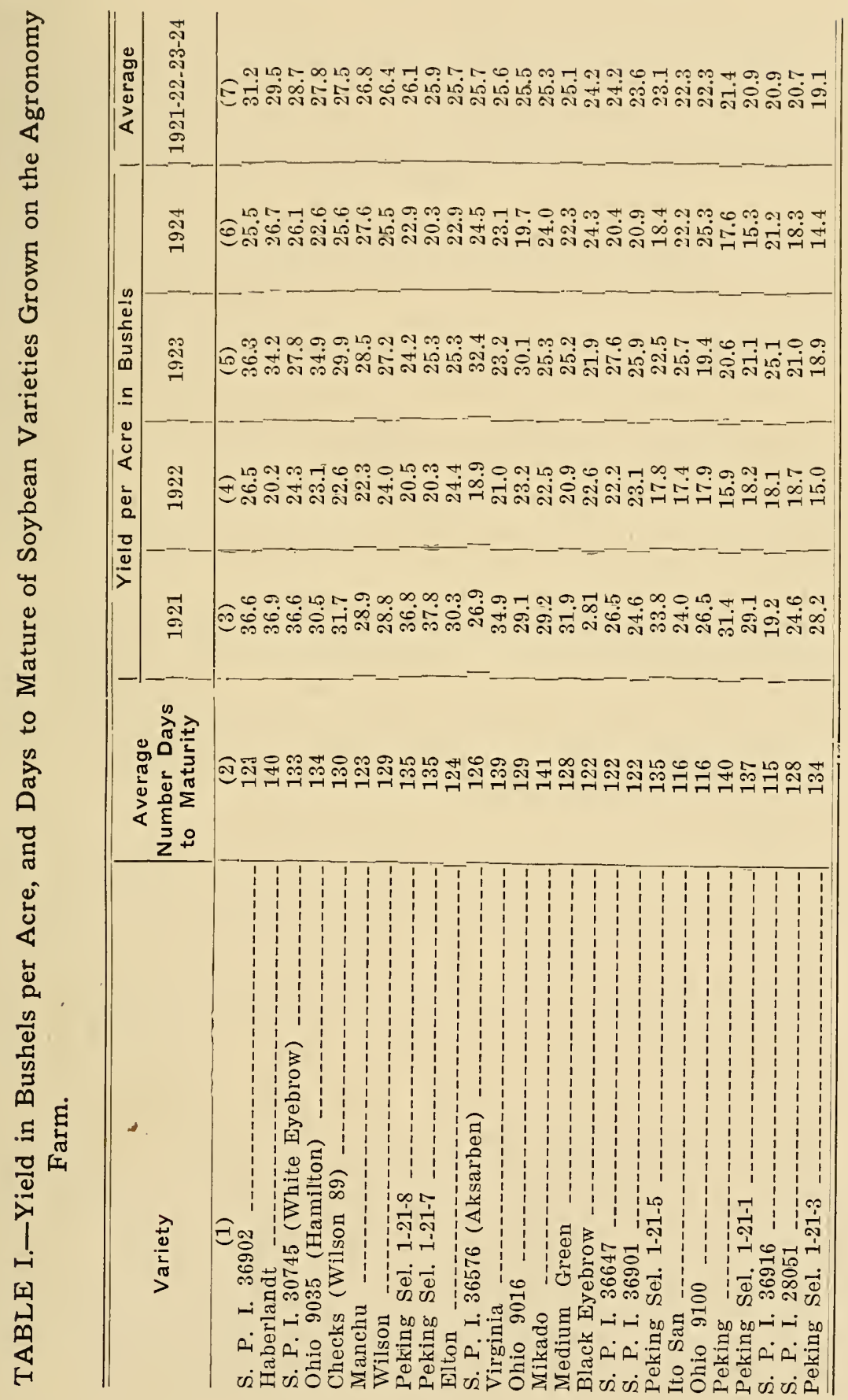


The varieties listed in Table I are arranged according to rank as determined by their average yields (column 7). The extreme difference in average yield between any two of the varieties producing the highest yields is 3.7 bushels per acre. The five varieties in the order of their rank are S. P. I. 36902, Haberlandt, S. P. I. 30745, Ohio 9035 (Hamilton), and the checks (Wilson 89). The chances are about twenty-seven to one that the difference in yield between S. P. I. 36902 and Wilson 89 is significant, that is, that the difference in yield obtained in this experiment is due to a real difference in the yielding capacity of the two varieties under the particular conditions and is not accidental.

There is little difference in average yield between Wilson 89 and the next ten highest yielding varieties, the extreme difference being 2.4 bushels per acre. The chancs are about eighteen to one that this difference is significant. Although the difference in average yield discussed here and in the preceeding paragraph are probably significant the differences themselves are not very great.

Considering the first fifteen varieties the greatest difference in average yield between any two consecutive varieties according to rank is that between those which occupy first and second place. The difference between their average yields is 1.7 bushels. S. P. I. 36902 produced a greater yield than Haberlandt in three of the four years the experiment was carried on.

Most of the soybeans grown in West Virginia are grown primarily for hay. The same varieties which were grown for seed on the Agronomy Farm were also grown for hay. The average height of the plants, the average number of days from planting to maturity for hay, and the yields of both green and air dry forage in tons per acre are listed in Table II. In column 1 the varieties are arranged according to rank with respect to average yield of air dry hay as shown i11 column 13.

An examination of column 2 shows that Virginia followed by Peking and Peking selections were the tallest varieties and S. P. I. 36916, Ohio 9100, Ito San, and S. P. I. 36647, were the shortest varieties in the test. In general the shortest varieties produced the lowest average yields of air dry hay and also were first to mature. Peking, the Peking selections, Virginia, Haberlandt, and Mikado, all of which required on the average approximately 110 days to mature for hay, were the latest maturing varieties in the experiment. 
ง

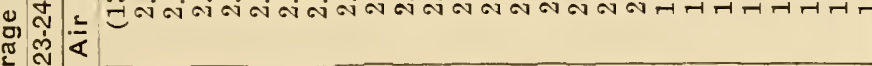
$\stackrel{人}{\sim}$

यद⿱

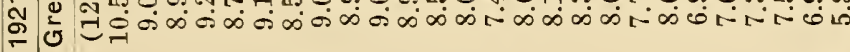

离

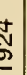

不 च

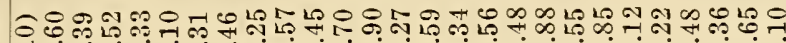
ט

ت

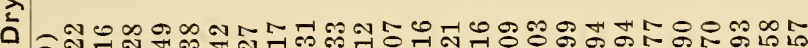

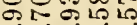

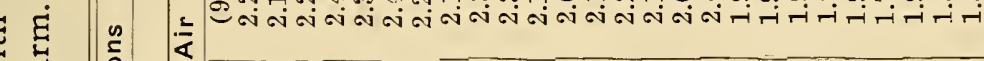

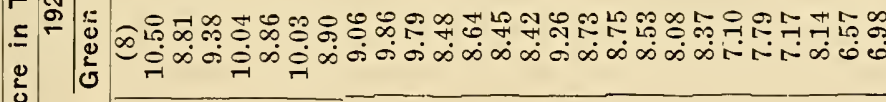

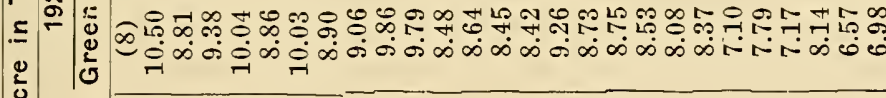

>1

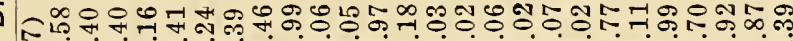

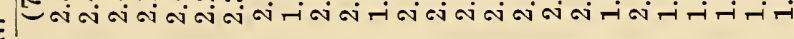
$<$

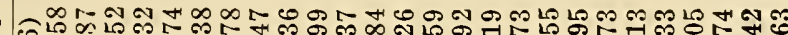

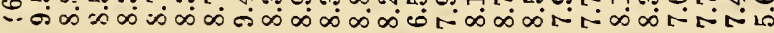

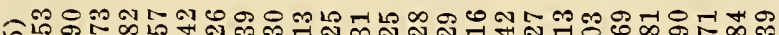
$-$ $\therefore$

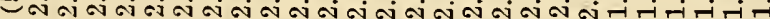

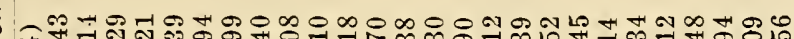
ป

唡 10

盢

n

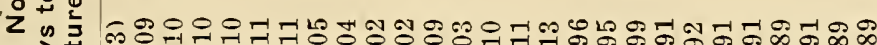
$\dot{x}+\frac{1}{10}$ \&经

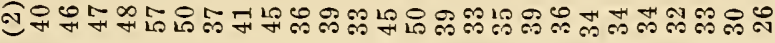

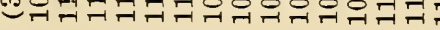
초드<smiles>C=C</smiles>

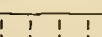


Haberlandt produced the highest average yield (2.60 tons) per acre of air dry forage (column 13). This variety produced on the average 0.21 tons more than the second highest yielding sort, Peking Selection 1-21-8. The odds are only three to one that this difference is significant and therefore no importance may be attached to it. An examination of columns $5,7,9$ and 11 shows that the difference in average yield between these two varieties is largely owing to the relatively high yield produced by Haberlandt in 1924 .

The three Peking selections 1-21-8, -1-21-5 and 1-21-7, which ranked second, third, and fourth respectively produced average yields approximately equal. The four next highest yielding varieties, Virginia, Peking, Medium Green, and Wilson produced average yields only slightly less than those of the Peking selections. Wilson 89 and Hamilton are tied for ninth place with respect to average yield of hay. The difference between the average yields of the former and Peking selection, $1-21-8$, is only 0.21 tons per acre. The chances are five to one that this difference is significant. In other words there is apparently little difference in the yielding capacity of these two varieties under the particular conditions of the experiment. Any of the varieties mentioned above may be expected to produce satisfactory yields under conditions similar to those which obtain at the Agronomy Farm.

It is interesting to note that Haberlandt which ranked first in average yield of hay ranked second in average yield of seed. The varieties Ohio 9035 (Hamilton), checks (Wilson 89), Wilson, Peking 1-21-8, Peking 1-21-7 and Virginia all of which produced relatively high yields of hay produced very satisfactory yields of seed also.

The average yield in tons per acre of green foliage is listed in column 12. The average yields of green material correspond roughly to the average yields of air dry hay. Each of the varieties Haberlandt, Peking, Ohio 9035 or Hamilton, Wilson, and Peking 1-21-8 produced an average yield of green forage in excess of nine tons per acre. In 1924 Haberlandt produced 11.6 tons (column 11) which was the highest yield of green forage produced by any variety during the four years of the experiment.

\section{DESCRIPTION OF VARIETIES}

A brief description of the varieties which produced high average yields of hay and also relatively high yields of seed, may be of interest.

Haberlandt-This is a late variety requiring an average of 109 
days to reach the proper stage for hay and 140 days to mature seed. The stems and leaves are rather coarse with an erect and bushy type of growth. The seed is straw yellow with a dark brown hilum or seed scar.

Hamilton-This variety was ready to harvest for hay or seed one week earlier as an average than Haberlandt. It is similar to Haberlandt in texture and habit of growth but the plants are somewhat more erect. The seed is large, brown in color, and has a brown hilum.

Wilson and Wilson 89-These varieties appear identical. The plants are slender, erect, and bushy and retain their leaves fairly well. Wilson is medium late requiring 104 days to reach the hay stage and 130 days to mature seed. The seed is black with a black hilum.

Peking-This is a late variety requiring about the same growing period as Haberlandt. The plants are similar to Wilson in growth, being fine textured, erect, and bushy. The seed is also black with a black hilum but is a little smaller than the Wilson.

Peking 1-21-7 and Peking 1-21-8-These are selections made from the Peking variety. They are somewhat similar to the variety from which they were selected except that they retain their leaves much better. In this respect they, together with Peking 1-21-5 excelled all other varieties in the test.

Virginia-This is a late variety also. The plants are slender and the tips are inclined to twine making this variety a desirable one to plant with corn where it is desired to grow the two crops together. The seed is olive brown witih a brown hilum.

\section{EXPERIMENTS AT THE MAGGIE SUBSTATION}

At the Maggie Substation located in Mason County near the Ohio River fourteen varieties of soybeans have been tested to determine their relative yield of seed and their relative yield of hay. The experiments which have been carried on for the past three years were located on first bottom land of high productivity. The varieties grown and the yield of seed in bushels per acre are listed in Table III. The varieties are arranged in column 1 according to rank based on average yield (column 5). 
TABLE III.-Yield in Bushels of Soybean Varieties Grown at the Maggie Substation.

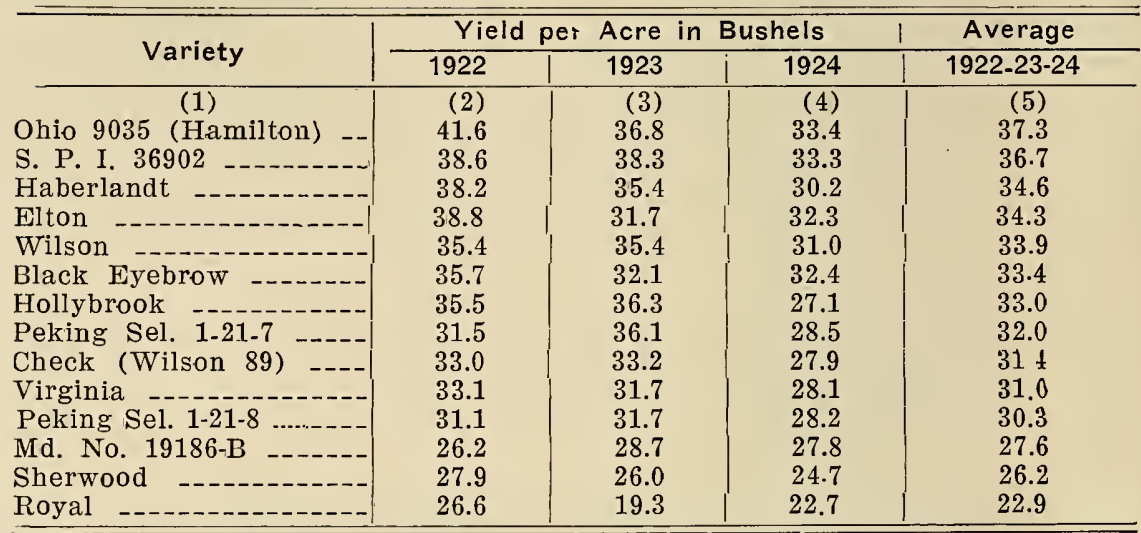

The two highest yielding varieties Ohio 9035 (Hamilton) and S. P. I. 36902 produced average yields for the three years of 37.3 and 36.7 bushels per acre respectively. The difference in yield between the two varieties is not significant. Haberlandt, Elton, and Wilson rank third, fourth, and fifth respectively in average yield.

The difference between the average yields of Hamilton and Wilson is 3.4 bushels. The chances are about twelve to one that this difference is significant. The difference in average yields between Hamilton and Haberlandt is only 2.7 bushels but the chances are about thirty-eight to one that this difference is significant. These facts clearly show that not only must the magnitude of the difference between average yields be considered but it is necessary to consider also the consistency of the difference in yield between the two varieties throughout the several years of the experiment.

An examination of columns 2, 3, 4 and 5 shows that in general those varieties which produced the highest average yields also produced relatively high yields in each of the three years the test was carried on. Two apparent exceptions to this general rule are Hollybrook and Peking Selection 1-21-7 which in 1923 were among the highest yielders.

It is interesting to note that the three varieties which produced the highest average yields of seed at Maggie ranked first, second, and fourth with respect to average yield of seed on the Agronomy Farm at Morgantown. These varieties are Hamilton, S. P. I. 36902, and Haberlandt. 
The same varieties which were grown for seed were also grown for hay. The average number of days from seeding until the plants were cut for hay and the yield of air dry forage of each variety are shown in Table IV. It will be noted that the average length of the growing period is based on data for two years only.

Column 2 shows that Black Eyebrow, Elton, and S. P. I. 36902 were the earliest maturing, and Virginia, Sherwood, Maryland No. 19186-B, and Royal were the latest maturing varieties in the experiment. The latest sorts produced the highest average yields of air dry hay.

TABLE IV.-Yield in Tons of Air Dry Hay and Days to Mature for Hay of Soybean Varieties Grown at the Maggie Substation.

\begin{tabular}{|c|c|c|c|c|c|}
\hline \multirow[t]{2}{*}{ Variety } & \multirow{2}{*}{$\frac{\left|\begin{array}{c}\text { Average } \\
\text { No. Days } \\
\text { to Mature }\end{array}\right|}{|1923-24|}$} & \multicolumn{3}{|c|}{ Yield per Acre in Tons } & \multirow{2}{*}{$\begin{array}{l}\text { Average } \\
1922-23-24\end{array}$} \\
\hline & & 1922 & 1923 & 1924 & \\
\hline (1) & $(2)$ & (3) & $(4)$ & (5) & $(6)$ \\
\hline Virginia & 110 & 3.47 & 2.70 & 3.14 & 3.10 \\
\hline Sherwood _. & 110 & 2.80 & 2.87 & 3.14 & 2.94 \\
\hline Md. No. 19186-B & 109 & 2.90 & 2.96 & 2.86 & 2.91 \\
\hline Royal -- - - & 109 & 2.98 & 2.73 & 2.99 & 2.90 \\
\hline Haberlandt & 102 & 2.82 & 2.75 & 3.10 & 2.89 \\
\hline Ohio 9035 (Hamilton) -- & 101 & 2.96 & 2.39 & 2.85 & 2.73 \\
\hline Peking Sel. 1-21-7 & 101 & 3.06 & 2.42 & 2.67 & 2.72 \\
\hline Wilson & 102 & 2.79 & 2.21 & 2.80 & 2.60 \\
\hline Check (Wilson 89) & 102 & 2.74 & 2.33 & 2.64 & 2.57 \\
\hline S. P. I. 36902 & 96 & 2.91 & 2.24 & 2.52 & 2.56 \\
\hline Peking Sel. 1-21.8 & 101 & 2.74 & 2.26 & 2.54 & 2.51 \\
\hline Hollybrook ...-- & 101 & 2.69 & 2.32 & 2.49 & 2.50 \\
\hline Black Eyebrow & 92 & 2.13 & 2.16 & 2.68 & 2.32 \\
\hline Elton & 95 & 2.42 & 1.94 & 2.37 & 2.24 \\
\hline
\end{tabular}

The yield data in columns $3,4,5$ and 6 show that there is little difference between any two of the five highest yielding varieties namely Virginia, Sherwood, Maryland No. 19186-B, Royal, and Haberlandt. In fact Student's method of analysis does not show a significant difference between any two of them. The chances are fifty-seven to one that the greater yield of Virginia over Hamilton is significant. The yield of the former exceeded that of the latter in 1922,1923 , and 1924 by $0.51,0.31$, and 0.29 tons respectively. The yields of Hamilton, Peking Selection 1-21-7, Wilson, and Wilson 89 dc not differ significantly.

In the varietal experiments at Maggie as well as those at Morgantown the yields of Wilson 89, the check, and Wilson are practically identical. In addition to similarity in yield there is also a sim- 
ilarity in the plant characteristics of these two forms and hence from a practical viewpoint there is little justification for distinguishing between them.

\section{SUMMARY}

1.-On the Agronomy Farm there were twenty-six and at the Maggie Substation fourteen varieties and selections of soybeans tested for yield of seed and hay. The experiments were carried on for four years at Morgantown and for three years at Maggie.

2.-The varieties which produced a relative high yield of hay per acre on the Agronomy Farm and at the same time produced a satisfactory yield of seed were Haberlandt, Peking, Peking 1-21-8, Peking 1-21-7, Virginia, Wilson, and Hamilton.

3.-At Maggie the varieties Virginia, Sherwood, Maryland No. 19186$\mathrm{B}$, Royal, and Haberlandt produced the highest average yields of hay per acre and Hamilton, S. P. I. 36902, Haberlandt, Elton, and Wilson produced the highest average yields of seed.

4.-The three Peking selections 1-21-8, 1-21-7, and 1-21-5 retained their leaves relatively longer than any other varieties in the experiments. 

$\checkmark$ 



\section{HECKMAN}

BINDERY INC.

\section{JUNE 99}

N. MANCHESTER INDIANA 46962 
Hathos

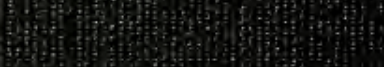

(10)

(4)

W

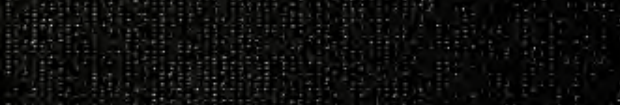

$\therefore$ (1)

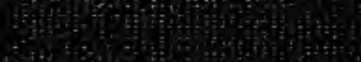

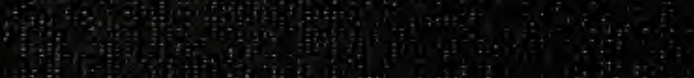

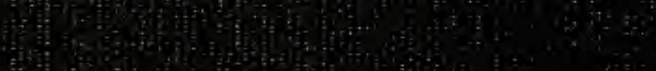

Whating

Hon (n)

Hinting

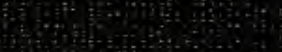

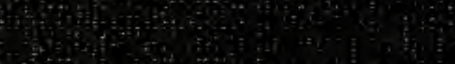

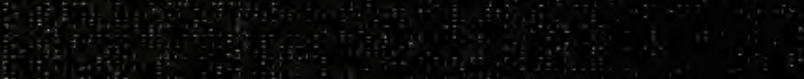

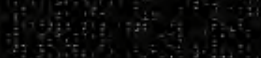

(4)

an

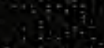

Thisis

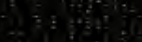

(1) 